\title{
Cropping systems strategy for effective management of Fusarium wilt in safflower
}

\author{
V. Nageswara Rao ${ }^{a, c, *}$, R. Kalpana Sastry ${ }^{b}$, P. Craufurd ${ }^{a}$, H. Meinke ${ }^{c}$, \\ D. Parsons ${ }^{c}$, T.J. Rego ${ }^{a}$, A. Rathore ${ }^{a}$ \\ a Research Program: Resilient Dryland Systems, International Crops Research Institute for the Semi-Arid Tropics (ICRISAT), Patancheru 502324, Andhra \\ Pradesh, India \\ ${ }^{\mathrm{b}}$ National Academy of Agricultural Research Management (NAARM), Rajendra Nagar 500030, Hyderabad, India \\ ${ }^{\mathrm{c}}$ Tasmanian institute of Agriculture, University of Tasmania, Hobart, TAS, Australia
}

\section{A R T I C L E I N F O}

\section{Article history:}

Received 8 November 2013

Received in revised form

13 November 2013

Accepted 13 November 2013

\section{Keywords:}

Chickpea

Cropping system

Fusarium oxysporum f. sp. carthami

Safflower

Wilt disease management

\begin{abstract}
A B S T R A C T
In many parts of India intensive cultivation of safflower on Vertisols appears to have aggravated the problem of Fusarium wilt in safflower due to the soil borne fungus, Fusarium oxysporum Schlecht f. sp. carthami Klisiwiez and Houstan (FOC). In a long-term field experiment at Patancheru, India, we evaluated four diverse dryland cropping systems that each included safflower for their effectiveness in controlling Fusarium wilt in safflower. Sorghum (rainy season crop) and safflower (post-rainy season crop) were grown every alternate year as a two-year rotation with: (1) sorghum intercropped with pigeonpea ( $\mathrm{S} / \mathrm{PP}-\mathrm{S}+\mathrm{SF})$; (2) cowpea intercropped with pigeonpea (C/PP $-\mathrm{S}+\mathrm{SF})$; (3) sorghum followed by chickpea $(\mathrm{S}+\mathrm{CP}-\mathrm{S}+\mathrm{SF})$; (4) sorghum followed by safflower $(\mathrm{S}+\mathrm{SF}-\mathrm{S}+\mathrm{SF})$. Continuous sorghum and safflower $(S+S F-S+S F)$ had higher Fusarium wilt incidence of fully wilted safflower plants (31\%) and a larger build-up of Fusarium propagules (1728 $\mathrm{cfu} \mathrm{g}^{-1}$ of soil) than other cropping systems. The inclusion of a legume such as chickpea in the rotation $(S+C P-S+S F)$ reduced wilt incidence (7\% fully wilted plants) and the level of inoculum in the soil to about $800 \mathrm{cfu} \mathrm{g}^{-1}$. There was a significant increase in safflower seed yield and biomass yield ( 883 and $1733 \mathrm{~kg} \mathrm{ha}^{-1}$, respectively) in the $\mathrm{S}+\mathrm{CP}-\mathrm{S}+\mathrm{SF}$ rotation compared with the $S+S F-S+S F$ rotation (605 and $1323 \mathrm{~kg} \mathrm{ha}^{-1}$, respectively). Nitrogen application at rates of 0 to $120 \mathrm{~kg} \mathrm{~N} \mathrm{ha}^{-1}$ had no effect on wilt incidence in safflower, but increased seed and biomass yield significantly. Intercrop rotations $(\mathrm{S} / \mathrm{PP}-\mathrm{S}+\mathrm{SF}$ and $\mathrm{C} / \mathrm{PP}-\mathrm{S}+\mathrm{SF})$ were less effective to manage the Fusarium wilt. The Area Under Disease Progress Curve (AUDPC) was almost 10 times higher in the $\mathrm{S}+\mathrm{SF}-\mathrm{S}+\mathrm{SF}$ rotation (2842) compared with the $S+C P-S+S F$ rotation (297). Wilt progress throughout the season in all four systems was linear, with significant differences in intercepts and rates of disease progress among cropping systems; the rate of disease progress was significantly greater in the $\mathrm{S}+\mathrm{SF}-\mathrm{S}+\mathrm{SF}$ rotation compared with the other three systems, which were similar. There was also a strong linear relationship between wilt incidence and the number of Fusarium propagules in the soil; regressions had the same slope but different intercepts in each system. There was no relationship between wilt incidence and seed yield; nitrogen had the largest effect on yields. A break from safflower cultivation for one year in the postrainy season by growing chickpea as a sequential crop after sorghum, or as an intercrop with pigeonpea and sorghum, combined with higher rates of nitrogen application to safflower appears to be an effective strategy for reducing Fusarium populations and sustaining safflower yield.
\end{abstract}

(c) 2013 Elsevier B.V. All rights reserved.
Abbreviations: AUDPC, area under disease progress curve; $\mathrm{CFU}$, colony forming units; ICRISAT, International Crops Research Institute for the Semi-Arid Tropics.

* Corresponding author. Tel.: +91 4030713436; fax: +91 4030713071.

E-mail addresses: v.nageswararao@cgiar.org, nageswararaovajja@gmail.com (V. Nageswara Rao).

\section{Introduction}

Safflower (Carthamus tinctorius Linn.) is grown on about $0.85 \mathrm{M}$ ha in more than 60 countries around the world between the latitudes of $50^{\circ} \mathrm{N}$ and $23^{\circ} \mathrm{S}$, mainly in India, Mexico, Kazakhstan, USA and Argentina (FAO, 2007). Safflower is a cold and droughttolerant crop (Majidi et al., 2011; Ozturk et al., 2008), able to extract soil water that is otherwise not available to the majority of dryland crops (Weiss, 2000). Safflower in India is grown mostly on residual soil moisture on Vertisol (black soil) areas as a post-rainy season 
sequential crop after rainy season sorghum, maize, or legumes, or as a post-rainy season intercrop with sorghum or chickpea.

Wilt incidence in safflower is widespread and has been reported from all safflower growing regions of the world (Claassen, 1949; McGregor and Hay, 1952; Mourashkinsky, 1926). Klisiewicz and Houston (1962) first reported that vascular wilt of safflower was incited by a form of Fusarium oxysporum f. sp. carthami and proved its pathogenicity on six wild species of Carthamus. Fusarium wilt of safflower is an endemic disease inflicting yield decline in the range of $40 \%$ to $80 \%$ with significant economic impact on Indian farmers of the Deccan Plateau (Kalpana Sastry, 1996). The intensity of the disease has gradually increased during the last decade, particularly in rainfed areas. Crop losses have led to a reduction in the cultivation of the crop (Kalpana Sastry and Chattopadhyay, 1997; Pedgoankar et al., 1990). Continuous mono-cropping of safflower in these areas is one of the factors believed to be responsible for the increase in disease incidence.

The pathogen survives as primary inoculum in seed; however, a greater threat is posed by this soil borne pathogen in the form of chlamydospores, which are perpetuated on host plant debris in the soil and retain their viability for many years (Chakrabarti, 1980). Haware et al. (1986) reported that F. oxysporum f. sp. ciceris (Padwick) Matuo \& K. Sato, causes wilt of chickpea; chlamydospores survive up to six years in the absence of chickpea as a host crop. The severity of Fusarium wilt is also directly related to the use of susceptible cultivars, high fungal population in the soil and safflower cropping in successive years (Kalpana Sastry et al., 1993). Long-term monocropping has also led to a productivity decline in kidney beans (Burke and Kraft, 1974), water melon (Hao et al., 2007), pigeonpea (Natarajan et al., 1985), and wheat (Smiley et al., 1970), all due to Fusarium wilts.

Biological control of soil borne pathogens has well recognised limitations, in the control of important soil borne pathogens, such as Plasmodiophora brassicae (Colhoun, 1958) and Verticillium albo-atrum (Wilhelm, 1975). On the other hand, crop sequences, intercrops and their rotations have long been recognized as effective long-term management strategies against soil borne pathogens (Curl, 1963; Huisman and Ashworth, 1976; Kollmorgen, 1974; Shipton, 1977). There have been few multi-seasonal field experiments that study the effects of cropping system rotations on soil borne diseases (Natarajan et al., 1985), and no information from long-term studies in dryland cropping systems that assesses disease build-up and its effects on crop yields. The particular motivation for this study was the observation that wilts in safflower increased in the long-term experiments at ICRISAT. The objectives of this research were: (i) to test different long-term cropping systems strategies for control of Fusarium wilt in safflower; (ii) to examine the effectiveness of nitrogen application as a management strategy in safflower; and (iii) to quantify the relationship among soil inoculum level, wilt incidence and safflower seed yield.

\section{Material and methods}

\subsection{Experimental design and cropping systems}

This study on Fusarium wilt of safflower was conducted at ICRISAT (lat. $17.5^{\circ} \mathrm{N}$, long. $78.2^{\circ} \mathrm{E}$ ) Patancheru, India during 1990-1993, following eight continuous years of a long-term cropping systems experiment established in 1983 to investigate legume contribution to soil fertility on a Vertisol (Rego et al., 1989). The experimental design was a split-plot with cropping systems as main plot $(12 \times 12 \mathrm{~m})$ treatments on eight sets of broad-bed $(100 \mathrm{~cm})$ and furrow $(50 \mathrm{~cm})(\mathrm{BBF})$ at $1.5 \mathrm{~m}$ width. The BBF system of land management on Vertisols was adopted (Kampen et al., 1981) in this experiment to avoid waterlogging, provide good aeration in
Table 1

Sequential and intercrop systems with safflower in post-rainy season every year or alternate year in the two-year rotations.

\begin{tabular}{|c|c|c|c|c|}
\hline \multicolumn{2}{|c|}{ 1st year (seasons) } & \multicolumn{2}{|c|}{ 2nd year (seasons) } & \multirow[t]{2}{*}{ Abbreviation } \\
\hline Rainy & Post-rainy & Rainy & Post-rainy & \\
\hline Sorghum+ & Safflower & Sorghum+ & Safflower & $\mathrm{S}+\mathrm{SF}-\mathrm{S}+\mathrm{SF}$ \\
\hline \multicolumn{2}{|c|}{ Cowpea/Pigeonpea } & Sorghum+ & Safflower & $\mathrm{C} / \mathrm{PP}-\mathrm{S}+\mathrm{SF}$ \\
\hline \multicolumn{2}{|c|}{ Sorghum/Pigeonpea } & Sorghum+ & Safflower & $S / P P-S+S F$ \\
\hline Sorghum+ & Chickpea & Sorghum+ & Safflower & $\mathrm{S}+\mathrm{CP}-\mathrm{S}+\mathrm{SF}$ \\
\hline
\end{tabular}

(/) Denotes intercropping, (+) denotes sequential cropping.

the root zone and enable greater storage of residual soil moisture sufficient to produce two crops in a sequential or intercrop system in a year. Each main plot was divided into four sub-plots that received $0,40,80$ or $120 \mathrm{~kg} \mathrm{Nha}^{-1}$ per crop, applied as urea to non-legume crops (sorghum, safflower) in all cropping systems. The long-term experiment included 10 dryland cropping systems; the four examined in this paper are most prevalent in farmers' fields in peninsular India (Table 1 ). Some agronomic results from this experiment have been published elsewhere (Sharma et al., 1996; Rego and Nageswara Rao, 2000); for consistency we applied the same nomenclature as in those previous publications, whereby $\mathrm{S}=$ sorghum, $\mathrm{C}=$ cowpea, $\mathrm{PP}=$ pigeonpea, $\mathrm{CP}=$ chickpea, $\mathrm{SF}$ = safflower; '/' = Intercrop, '+' = sequential crop, and '-' indicate next year's rotation). Sorghum (rainy season crop) and safflower (post-rainy season crop) were grown every alternate year as a two-year rotation with either: (1) sorghum intercropped with pigeonpea $(\mathrm{S} / \mathrm{PP}-\mathrm{S}+\mathrm{SF})$; (2) cowpea intercropped with pigeonpea $(\mathrm{C} / \mathrm{PP}-\mathrm{S}+\mathrm{SF})$; (3) sorghum followed by chickpea $(\mathrm{S}+\mathrm{CP}-\mathrm{S}+\mathrm{SF})$; and (4) sorghum followed by safflower $(S+S F-S+S F)$. The crops grown during the rainy season were cowpea (Vigna sinesis L. Savi ex. Harsk.), cultivar EC 6216 and sorghum (Sorghum bicolor L. Moench), cultivar CSH 6. The post-rainy season crops were chickpea (Cicer arietinum L.), cultivar Annigeri which was wilt susceptible; pigeonpea (Cajanus cajan L. Huth), cultivar ICP-1 which was wilt susceptible, and safflower (C. tinctorius Linn.) cultivar Manjeera, also wilt susceptible. Both phases of each rotation were cultivated every year as mirror images (e.g. S/PP $-\mathrm{S}+\mathrm{SF}$ and $\mathrm{S}+\mathrm{SF}-\mathrm{S} / \mathrm{PP}$ ). Stubble of diseased plants was incorporated in the same plot each year.

\subsection{Disease assessment}

After qualitative differences in disease pressure became apparent eight years (four cycles) into the long-term rotation experiment, we commenced quantitative disease observations for 3 years from 1990-1991 to 1992-1993 for the relevant rotations. Wilt was assumed to affect seedling survival (Nene et al., 1991) and to have caused wilt symptoms on surviving seedlings and plants. Accordingly, we counted plants at the end of the seedling phase (15 days after emergence) and assumed that the difference in survival from the initial plant population was due to wilt. Wilt incidence on surviving plants after seedling phase was then scored as 'full wilt' if a plant exhibited characteristic wilt symptoms and was dead at any stage of the crop. Full wilt was calculated as the number of full wilt plants divided by the population stand at the end of the seedling phase, and expressed in terms of the percentage of full wilt at 30 , $45,60,75,90$, and 105 days, coinciding with the end of vegetative, rosette, flowering, grain filling and capsule maturity growth stages of the crop, respectively. Wilt data were then expressed as a percentage of the total number of dead and infected plants relative to the initial plant population.

At each observation, FOC isolations were made from infected stem, collar and root of diseased safflower plants on modified selective Czapeck-Dox agar medium. The composition of standard Czapeck-Dox agar medium is sodium nitrate as the sole source of 
nitrogen, sucrose as preferential source of carbon for $F$. Oxysporum, Di-potassium phosphate as a buffer in the medium. Magnesium sulphate, potassium chloride and ferrous sulphate serve as sources of essential ions in the medium. This medium was further modified by addition of $50 \mathrm{mg}$ PCNB non-toxic to F. oxysporum f. sp. carthami for selective isolation of fungus in soils; $25 \mathrm{mg}$ malachite green for better differentiation of hyphal fragments from plant tissue, and to facilitate enumeration of propagules, $75 \mathrm{mg}$ dicrysticin-S (mixture of streptomycin and procaine and sodium penicillin-G) and $2 \mathrm{~g}$ yeast extract per litre of medium as an energy source and for characteristic pigmentation (Sharma and Singh, 1973). Plates were incubated for 8 days at $20 \pm 2{ }^{\circ} \mathrm{C}$ with $12 \mathrm{~h}$ of alternating dark and light periods. We confirmed the presence of $F$. oxysporum f. sp. carthami, by conducting microscopic studies for identifying morphological traits of the spores and colony forming units of FOC isolate responsible for the wilt in safflower. In our observations, macroconidia counts exceeded the microconidia counts of the fungal spores. Macroconidia were oval and septa were thinwalled, the size of 1 and 3 septate conidia was $20-32 \times 3.7 \mu \mathrm{m}$. These morphological traits correlate to FOC (IMI186541) isolate reported by Chakrabarti (1979) collected from Varanasi, Northern India. Chlamydospores were rarely formed within 8 weeks of culture. We evaluated FOC for pathological manifestations by infecting the stems of young healthy safflower plants with isolate of FOC in pot-culture study to produce disease symptoms and verified the FOC pathogenicity on safflower.

Disease progression, a useful quantitative measure of disease intensity at each growth stage was calculated as the area under the disease progress curve (AUDPC) using Eq. (1). AUDPC is generally considered a critical factor for estimating crop yield (Nagarajan and Muralidahran, 1995). We used the trapezoidal method (Madden et al., 2007) to discretize the time variable $t_{i}(30,45,60,75,90$ and 105 days). We calculated the mean disease intensity between each pair of adjacent time periods following wilt incidence sampling and multiplied by the number of days in the interval between two points.

$A_{K}=\sum_{i=1}^{N i-1} \frac{\left(y_{i}+y_{i+1}\right)}{2}\left(t_{i+1}-t_{i}\right)$

we consider $y_{i}=y_{0}$ at 30 days, as the initial infected plant count, i.e. the first observation $t_{i=} t_{0} ; k$ is the area under disease progression between each time period, and $A_{k}$ is the total accumulated AUDPC during all time periods $\left(t_{k}\right)$.

\subsection{Fungal propagule counts}

Fusarium survives in the soil as chlamydospores (propagules) in the absence of a host. Hence we determined inoculum density in the soil as colony-forming units (cfu) per g of soil in soil samples collected from the $0-15 \mathrm{~cm}$ depth after the harvest of the first crop, $7 \mathrm{~d}$ before the sowing of safflower each season. Each soil sample was a composite of soil cores from five locations in each plot. These composite samples were shade dried for $48 \mathrm{~h}$ and ground to pass a 250-mesh sieve. A sub-sample of $20 \mathrm{mg}$ was systematically sprinkled aseptically on $20 \mathrm{ml}$ of modified Czapeck-Dox medium (Kalpana Sastry and Jayaraman, 1993) in sterile petri plates, and then incubated in the dark for 3 days. These plates were further incubated for 5 more days at $20 \pm 2{ }^{\circ} \mathrm{C}$ for $12 \mathrm{~h}$ of alternate cycles of dark and light periods. For each sample ten replicates were made. The first appearance of cfu usually started on 4th day of incubation (Kalpana Sastry et al., 1993); final counts were taken on the 8th day of incubation. In ten replications of these samples, colony-forming units (cfu) were counted using a colony counter, which enumerates only live fungal cfu. Colony-forming units of FOC strain produced a symptomatic dazzling white pigmentation in the
Czapeck-Dox medium. Chakrabarti (1979) reported that cfu of FOC physiological variant (IMI 186541) produced similar dazzling white pigmentation with Martin's medium. Rajendranagar geographical isolate of FOC also developed dazzling white pigmentation of the cfu, which was reported by Kalpana Sastry and Chattopadhyay (2003) along with 15 other isolates of FOC they collected across India and deposited in Indian Type Culture Collection, (ITCC), IARI, New Delhi. The FOC in soils was ascertained by combination of observations of morphological traits of cfu in culture medium and taxonomic characterization through microscopic examination of each fungal colony for corroboration with notified characters of FOC strains reported in India.

\subsection{Assessment of crop yields}

The seed yield and total biomass of safflower were assessed from 1983 to 1992 . Crop samples were harvested from a $9-\mathrm{m}^{2}$ area of each sub-plot and yields calculated as $\mathrm{kg} \mathrm{ha}^{-1}$. Sorghum yields were also measured on the same areas.

\subsection{Statistical analysis}

Safflower seed yield and biomass data were analysed as a multi-year, split-plot design, using the SAS MIXED procedure (SAS Institute Inc, 2009, SAS V 9.3) with cropping systems as main-plots, and nitrogen levels as sub-plots. Similar analyses were used for percentage of full wilt and Fusarium chlamydospore population (propagules as cfug ${ }^{-1}$ of soil). Percentage of full wilt was calculated and the arc sin transformation was used to attain normality of errors. Disease progression was analysed as percentage incidence and AUDPC. Regressions were compared using GENSTAT version 14 (Payne et al., 2011). A simple linear regression was first fitted to all data ignoring the groups. To test for parallelism or significant differences in intercepts among these regressions, groups were added as a factor. If the analysis showed that different intercepts were needed (i.e. there was significant increases in the variance accounted for), then the model was extended to test whether regressions (slopes + intercepts) were significantly different. Fitted equations for each of the regressions were provided along with the caption of each figure.

\section{Results}

\subsection{Effect of cropping system rotations on safflower yield}

There were significant effects of year, cropping system, nitrogen and the first order interactions on safflower grain and biomass yield over the 10 years of the experiment (Table 2). Over the 10 years safflower yield declined in all four cropping system rotations (Fig. 1); sorghum yields did not show the same decline (Rego and Nageswara Rao, 2000). All systems showed considerable variability in yield year to year. The highest sorghum grain yield was in the $\mathrm{C} / \mathrm{PP}-\mathrm{S}+\mathrm{SF}$ cropping system, while the highest safflower grain yield was in the $\mathrm{S}+\mathrm{CP}-\mathrm{S}+\mathrm{SF}$ system (Fig. 2). The yield of sorghum and safflower did not exhibit any correlation with either monthly or seasonal rainfall (JJASOND) during the period.

\subsection{Effect of nitrogen on safflower yield and wilt}

Nitrogen significantly increased safflower seed yield and dry matter production, and there were interactions with cropping system and year $(P<0.001)$. Nitrogen increased seed yield from $207 \mathrm{~kg} \mathrm{ha}^{-1}$ at $0 \mathrm{~N}$ to $896 \mathrm{~kg} \mathrm{ha}^{-1}$ at $120 \mathrm{~kg} \mathrm{~N} \mathrm{ha}^{-1}$ across all cropping systems over the period 1983-1993 (Table 3). At 0 N seed yields ranged from $231 \mathrm{~kg} \mathrm{ha}^{-1}$ in $\mathrm{S}+\mathrm{SF}-\mathrm{S}+\mathrm{SF}$ to $409 \mathrm{~kg} \mathrm{ha}^{-1}$ 
Table 2

SAS Proc mixed analysis of variance table with $F$-values and probabilities for all variables.

\begin{tabular}{|c|c|c|c|c|c|c|c|}
\hline \multirow[t]{2}{*}{ Source of Variance } & \multicolumn{7}{|c|}{ F values and Probabilities } \\
\hline & df & Biomass $\left(\mathrm{kg} \mathrm{ha}^{-1}\right)$ & Grain yield $\left(\mathrm{kg} \mathrm{ha}^{-1}\right)$ & df & $\%$ full wilt & $\%$ seedling survival & Propagules (cfu g ${ }^{-1}$ soil) \\
\hline $\operatorname{Year}(\mathrm{Y})$ & 9 & $66^{* * *}$ & $43.5^{* * *}$ & 2 & $0.3 \mathrm{~ns}$ & $141^{* * *}$ & $18^{* *}$ \\
\hline Cropping system (CS) & 3 & $17^{* * *}$ & $23^{* * *}$ & 3 & $3^{*}$ & $96^{* * *}$ & $28^{* * *}$ \\
\hline $\mathrm{Y} \times \mathrm{CS}$ & 27 & $2^{* *}$ & $2^{*}$ & 6 & 2 ns & $18^{* * *}$ & $3.0 \mathrm{~ns}$ \\
\hline Nitrogen $(\mathrm{N})$ & 3 & $440^{* * *}$ & $387^{* * *}$ & 3 & $0.6 \mathrm{~ns}$ & $0.9 \mathrm{~ns}$ & $0.3 \mathrm{~ns}$ \\
\hline $\mathrm{CS} \times \mathrm{N}$ & 9 & $3^{* *}$ & $4^{* * *}$ & 9 & $0.6 \mathrm{~ns}$ & $1.2 \mathrm{~ns}$ & $0.4 \mathrm{~ns}$ \\
\hline $\mathrm{Y} \times \mathrm{N}$ & 27 & $19^{* * *}$ & $12^{* * *}$ & 6 & $1.3 \mathrm{~ns}$ & $3.6^{* *}$ & $0.6 \mathrm{~ns}$ \\
\hline $\mathrm{Y} \times \mathrm{CS} \times \mathrm{N}$ & 81 & $1.0 \mathrm{~ns}$ & $1.5 \mathrm{~ns}$ & 18 & $0.6 \mathrm{~ns}$ & $4.4^{* * *}$ & $0.7 \mathrm{~ns}$ \\
\hline
\end{tabular}

ns: Not significant.

${ }^{*}$ Prob. $<0.05$.

** Prob. $<0.001$.

*** Prob $<0.0001$.
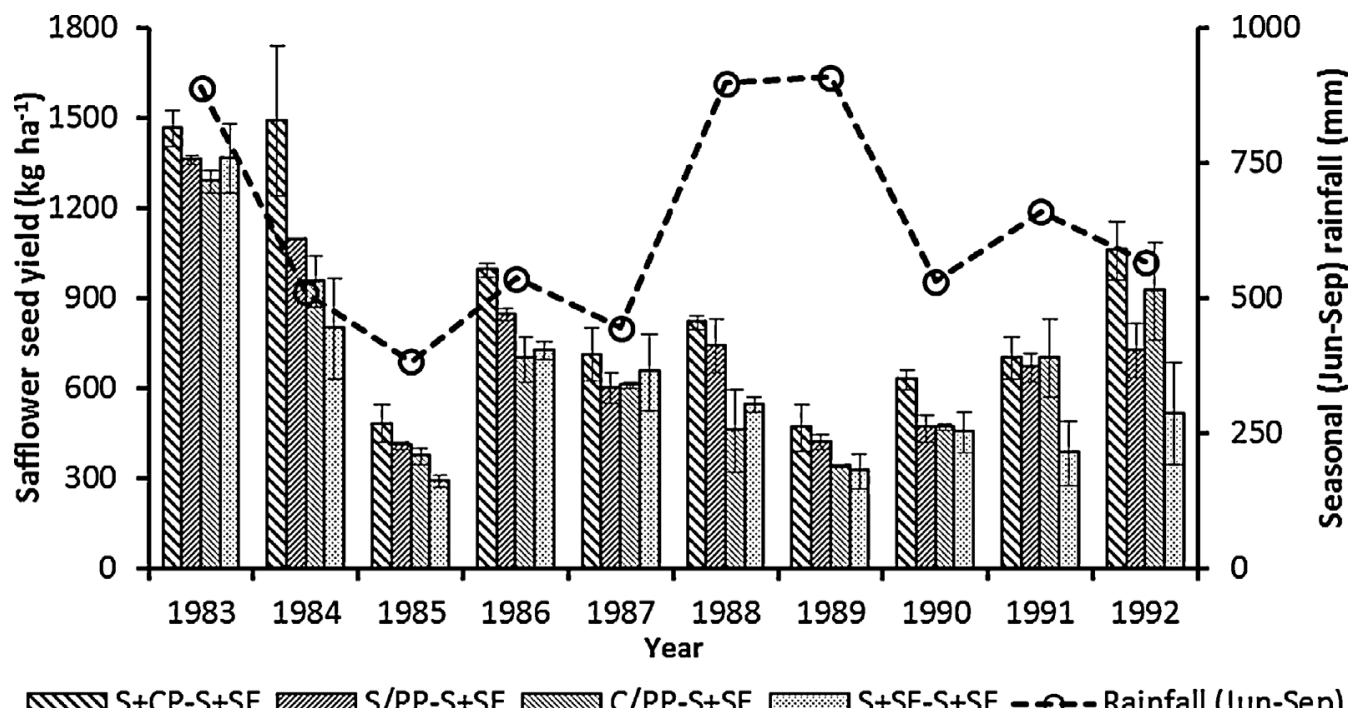

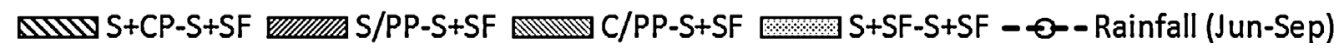

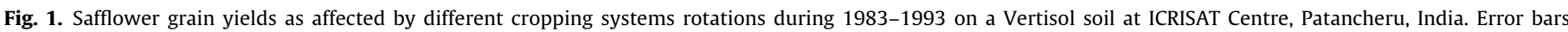
indicate \pm SE.D (Standard Error of Difference) for the cropping system.
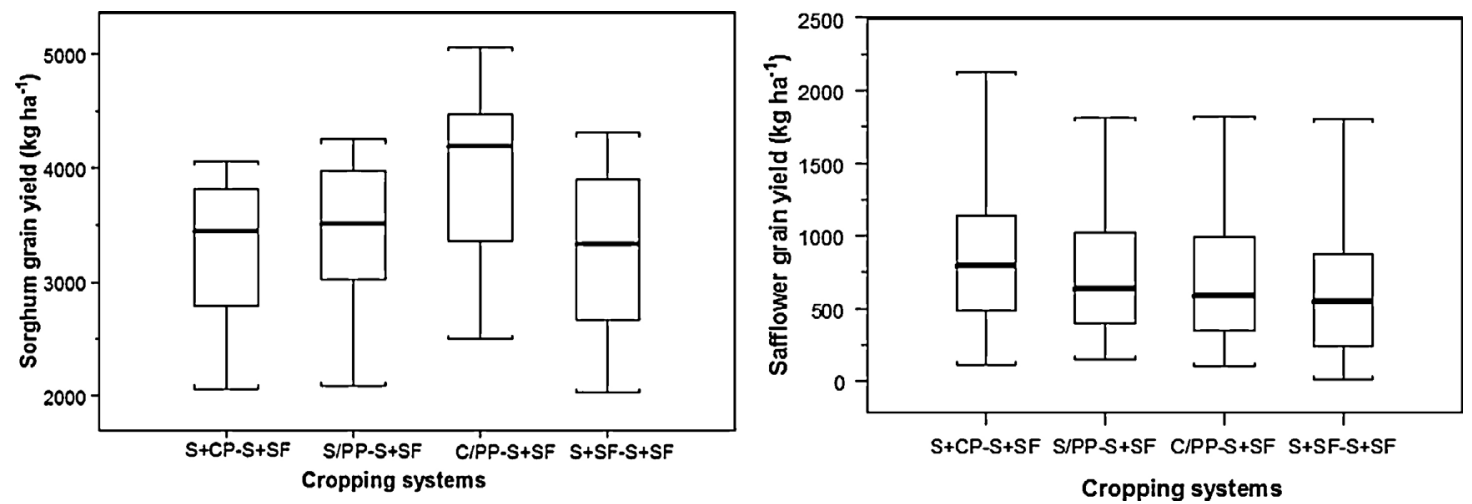

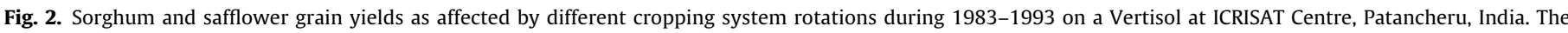
horizontal line in the box indicates the median of the data values.

Table 3

Effect of nitrogen levels on mean safflower seed and total dry matter yield (1983-1993), disease incidence and soil fungal population during 1990-1993 crop seasons.

\begin{tabular}{|c|c|c|c|c|}
\hline \multirow[t]{2}{*}{ Nitrogen levels } & \multicolumn{2}{|c|}{ Yield attributes $\left(\mathrm{kg} \mathrm{ha}^{-1}\right)$} & \multirow[t]{2}{*}{$\%$ full wilt } & \multirow[t]{2}{*}{ Fungal propagules $\left(\mathrm{cfug}^{-1}\right)$} \\
\hline & Seed & $\begin{array}{l}\text { Total dry } \\
\text { matter }\end{array}$ & & \\
\hline NO & 207 & 508 & 16.1 & 1173 \\
\hline N40 & 638 & 1312 & 19.5 & 1218 \\
\hline N80 & 829 & 1761 & 17.5 & 1185 \\
\hline N120 & 896 & 1921 & 18.0 & 1185 \\
\hline SE.D \pm & 65 & 115 & 0.03 & 47.7 \\
\hline
\end{tabular}

SE.D $\pm=$ Standard error of difference. 
Table 4

Effect of nitrogen levels on mean safflower seed yield across different cropping systems during 1983-1993 crop seasons.

\begin{tabular}{lllll}
\hline \multirow{2}{*}{ Cropping Systems } & \multicolumn{4}{l}{ Nitrogen applied $\left(\mathrm{kg} \mathrm{ha}^{-1}\right)$} \\
\cline { 2 - 5 } & $\mathrm{N}-0$ & $\mathrm{~N}-40$ & $\mathrm{~N}-80$ & $\mathrm{~N}-120$ \\
\hline $\mathrm{S}+\mathrm{SF}-\mathrm{S}+\mathrm{SF}$ & 231 & 597 & 773 & 818 \\
$\mathrm{C} / \mathrm{PP}-\mathrm{S}+\mathrm{SF}$ & 331 & 655 & 790 & 956 \\
$\mathrm{~S} / \mathrm{PP}-\mathrm{S}+\mathrm{SF}$ & 408 & 657 & 900 & 984 \\
$\mathrm{~S}+\mathrm{CP}-\mathrm{S}+\mathrm{SF}$ & 409 & 836 & 1026 & 1260 \\
$\mathrm{SE} . \mathrm{D} \pm$ & 48.01 & & & \\
\hline
\end{tabular}

SE.D $\pm=$ Standard error of difference.

in $\mathrm{S}+\mathrm{CP}-\mathrm{S}+\mathrm{SF}$, and at $120 \mathrm{~N}$ from 818 to $1260 \mathrm{~kg} \mathrm{ha}^{-1}$, respectively (Table 4). However, years had no effect on wilt incidence in safflower or the number of fungal propagules across all cropping systems during 1990-91 to 1992-93 (Table 5) but seed yield increased in response to nitrogen levels across years during 199091 to $1992-93$ (Table 6).

\subsection{Number of Fusarium propagules and disease progression}

The number of Fusarium propagules $\left(\mathrm{cfug}^{-1}\right)$ present in the soil significantly increased across all cropping systems from 926 to $1409 \mathrm{cfu} \mathrm{g}^{-1}$ during the three years of observations (Table 5). However, there were significant differences $(P<0.01)$ between cropping systems with the highest build-up in $\mathrm{S}+\mathrm{SF}-\mathrm{S}+\mathrm{SF}$ and the lowest build-up of propagules in $\mathrm{S}+\mathrm{CP}-\mathrm{S}+\mathrm{SF}$ and $\mathrm{S} / \mathrm{PP}-\mathrm{S}+\mathrm{SF}$ (Table 5). Seedling survival also varied significantly among cropping systems, years and interactions with $\mathrm{N}(P<0.001)$. Seedling survival is mainly influenced year $x$ cropping system effect; the interaction was statistically significant. Further, $\mathrm{N}$ interaction with these two factors also occurred. An unusually high mortality of seedlings in two replications of $\mathrm{N} 80$ treatments in C/PP $-\mathrm{S}+\mathrm{SF}$ during 1992 may be attributed to plot-specific soil problem, and might not be an indication for an effect by FOC. The mean seedling survival over the three years from $1990 / 91$ to $1992 / 93$ varied from $87 \%$ in $S+C P-S+S F$ to $69 \%$ in $\mathrm{S}+\mathrm{SF}-\mathrm{S}+\mathrm{SF}$. There was a strong negative relationship between seedling survival and the number of propagules in the soil (Fig. 3), with significant differences in the intercepts but not the slope ( slope $=0.011 \%$ wilt per $\mathrm{cfu}^{-1} \mathrm{~g}^{-1}$ ) between cropping systems. Hence cropping systems with a higher initial number of propagules had lower seedling survival.

There was an effect $(P<0.05)$ of cropping systems on wilt incidence (the percentage of plants that became infected and fully wilted and those that died during the season) but no effect of years or nitrogen (Table 2). Mean wilt incidence over the three years ranged from $7.2 \%$ in $\mathrm{S}+\mathrm{CP}-\mathrm{S}+\mathrm{SF}$ to $30.7 \%$ in $\mathrm{S}+\mathrm{SF}-\mathrm{S}+\mathrm{SF}$ $(\mathrm{SED} \pm 0.08)$, data points at 105 shown in Fig. 4. Wilt incidence increased from $14 \%$ in the first year to $21 \%$ in the second year and was similar in the third year, even though the inoculum in soil increased from 926 to $1409 \mathrm{cfu} \mathrm{g}^{-1}$ over the same period (Table 5). In all four cropping systems, wilt increased throughout the season in a linear manner, but with significant differences among

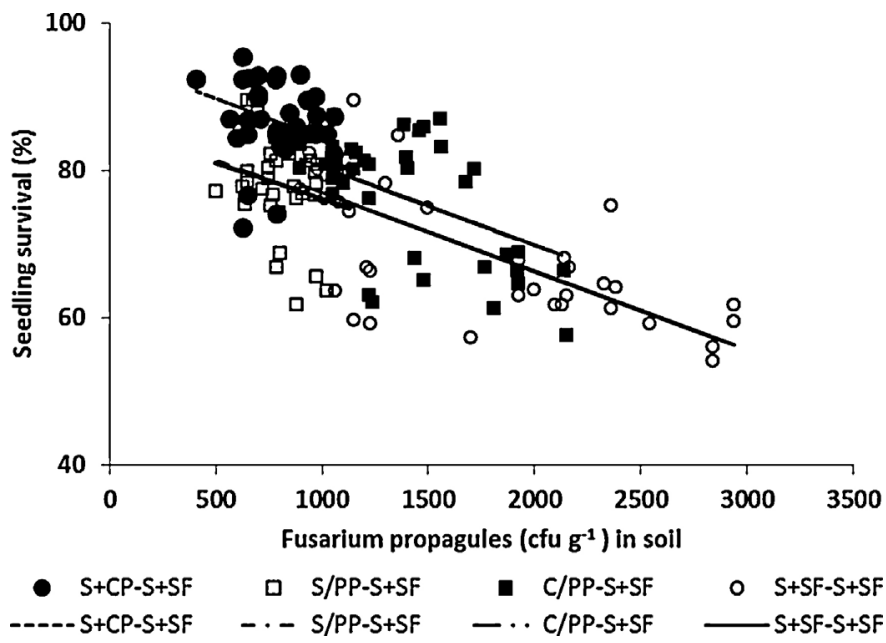

Fig. 3. Relationship of Fusarium propagules in the soil affecting seedling survival of safflower under four cropping systems. (Regressions for $\mathrm{S}+\mathrm{CP}-\mathrm{S}+\mathrm{SF}$ : $Y=95.07+(-0.01068 \times x) ; \quad \mathrm{S} / \mathrm{PP}-\mathrm{S}+\mathrm{SF}: \quad Y=86.76+(-0.01068 \times x) ; \mathrm{C} / \mathrm{PP}-\mathrm{S}+\mathrm{SF}$ : $Y=91.21+(-0.01068 \times x) ; \mathrm{S}+\mathrm{SF}-\mathrm{S}+\mathrm{SF}: Y=87.7+(-0.01068 \times x))$.

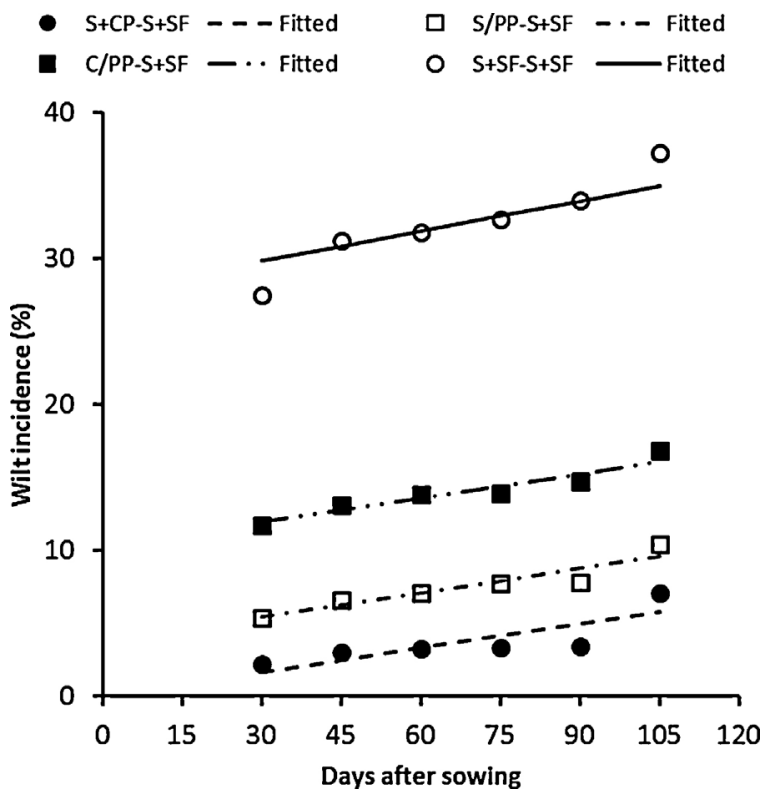

Fig. 4. Linear regressions fitted between days after sowing and wilt incidence (\%) and cumulative Area Under Disease Progress Curve (AUDPC) during the season in each of the four cropping systems.(Regressions for $\mathrm{S}+\mathrm{CP}-\mathrm{S}+\mathrm{SF}$ : $Y=(-0.026)+0.05466 \times x ; \quad \mathrm{S} / \mathrm{PP}-\mathrm{S}+\mathrm{SF}: \quad Y=3.832+0.05466 \times x ; \mathrm{C} / \mathrm{PP}-\mathrm{S}+\mathrm{SF}:$ $Y=10.325+0.05466 \times x ; \mathrm{S}+\mathrm{SF}-\mathrm{S}+\mathrm{SF}: Y=27.75+0.0687 \times x)$.

cropping systems in the initial incidence (i.e. intercept) at the vegetative stage (Fig. 4). The comparison of linear regressions indicated that the rate of progression of the disease was similar in all systems (slope $=0.055 \% \mathrm{~d}^{-1}$ ) except $\mathrm{S}+\mathrm{SF}-\mathrm{S}+\mathrm{SF}$, where the rate

Table 5

Population dynamics of Fusarium oxysporum f. sp. carthami in soil as affected by different cropping systems from 1990-1991 to $1992-1993$.

\begin{tabular}{|c|c|c|c|c|c|c|}
\hline \multirow[t]{2}{*}{ Year } & \multirow[t]{2}{*}{$\%$ full wilt } & \multirow[t]{2}{*}{ Fungal propagules ( $\mathrm{cfu} \mathrm{g}^{-1}$ soil) } & \multicolumn{4}{|c|}{ Fungal propagules (year $\times$ cropping system) $\left(\mathrm{cfu} \mathrm{g}^{-1}\right.$ soil $)$} \\
\hline & & & $\mathrm{S}+\mathrm{CP}-\mathrm{S}+\mathrm{SF}$ & $\mathrm{S} / \mathrm{PP}-\mathrm{S}+\mathrm{SF}$ & $\mathrm{C} / \mathrm{PP}-\mathrm{S}+\mathrm{SF}$ & $\mathrm{S}+\mathrm{SF}-\mathrm{S}+\mathrm{SF}$ \\
\hline 1990-1991 & 13.8 & 926 & 696 & 771 & 1110 & 1126 \\
\hline 1991-1992 & 21.1 & 1236 & 868 & 842 & 1386 & 1850 \\
\hline $1992-1993$ & 18.3 & 1409 & 809 & 880 & 1741 & 2207 \\
\hline Mean & 17.7 & 1190 & 791 & 831 & 1412 & 1728 \\
\hline $\mathrm{SE} . \mathrm{D} \pm$ & 0.10 & $81.5^{* *}$ & 203.2 & & & \\
\hline
\end{tabular}

Note: Means of three replications. SE.D $\pm=$ Standard error of difference.

${ }^{* *}$ Prob. $<0.001$. 


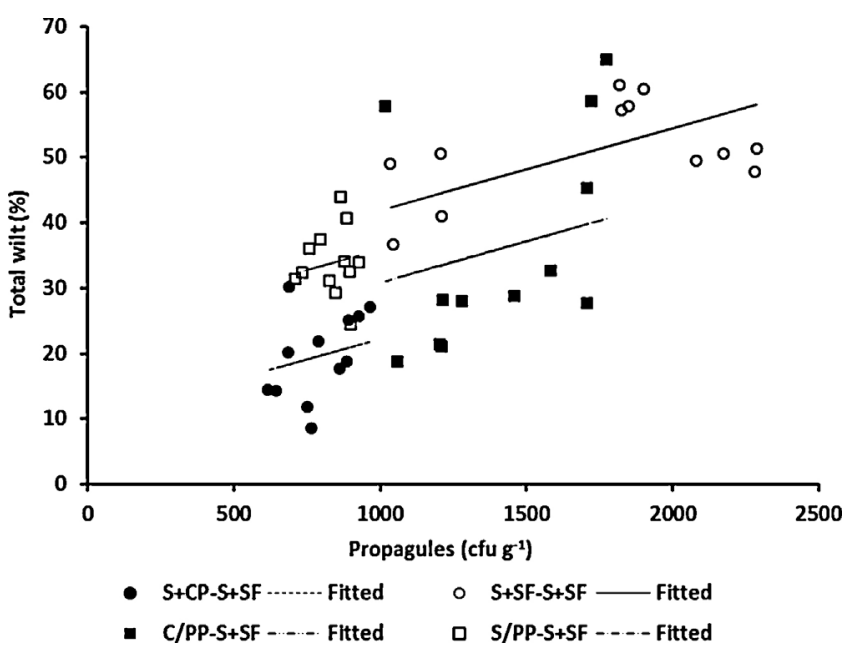

Fig. 5. Linear relationship of Fusarium propagules in the soil affecting total wilt of safflower plants under four cropping systems. (Regressions for $\mathrm{S}+\mathrm{CP}-\mathrm{S}+\mathrm{SF}$ : $Y=9.62+0.01259 \times x ; \quad \mathrm{S} / \mathrm{PP}-\mathrm{S}+\mathrm{SF}: \quad Y=23.34+0.01259 \times x ; \quad \mathrm{C} / \mathrm{PP}-\mathrm{S}+\mathrm{SF}$ : $Y=18.29+0.01259 \times x ; \mathrm{S}+\mathrm{SF}-\mathrm{S}+\mathrm{SF}: Y=29.29+0.01259 \times x)$.

Table 6

Effect of year and nitrogen levels on mean safflower seed yield during 1990-1993 crop seasons.

\begin{tabular}{lllll}
\hline \multirow{2}{*}{ Year } & \multicolumn{4}{l}{ Nitrogen applied $\left(\mathrm{kg} \mathrm{ha}^{-1}\right)$} \\
\cline { 2 - 5 } & N-0 & N-40 & N-80 & N-120 \\
\hline $1990-1991$ & 129 & 451 & 657 & 788 \\
$1991-1992$ & 190 & 633 & 806 & 827 \\
$1992-1993$ & 302 & 831 & 1024 & 1072 \\
SE.D \pm & 86.8 & & & \\
\hline
\end{tabular}

S.E.D $\pm=$ standard error of difference.

was greater $\left(P<0.05\right.$, slope $\left.=0.069 \% \mathrm{~d}^{-1}\right)$. The cumulative AUDPC which is the sum of AUDPC at each growth stage from $30 \mathrm{~d}$ to $105 \mathrm{~d}$ was greatest in the $\mathrm{S}+\mathrm{SF}-\mathrm{S}+\mathrm{SF}$ system $(\mathrm{AUDPC}=2842)$ and lowest in the $S+C P-S+S F$ system, $(A U D P C=297)$.There was no correlation between seasonal (correlation coefficient " $r$ " in the range of -0.056 to 0.149 for different cropping systems) or individual monthly (September, October, November, and December) rainfall with disease expression.

We calculated the 'percentage of seedling death' by deducting percentage of 'seedling survival' from 100. 'Total wilt' was calculated as the summation of percentage of full wilt plus percentage of seedling death. There was a significant relationship between the percentage total wilt incidence and the number of propagules in each of the three years in each system (Fig. 5). A comparison of regressions indicated that the four systems had a common slope $\left(0.013 \% \mathrm{cfug}^{-1}\right)$, but different intercepts $(P<0.014)$. The number of soil propagules in the $\mathrm{S}-\mathrm{CP}+\mathrm{S}-\mathrm{SF}$ and $S / P P-S+S F$ cropping systems was similar over the three years and $\mathrm{N}$ treatments $\left(500-1000 \mathrm{cfu}^{-1}\right)$, but the $\mathrm{S} / \mathrm{PP}-\mathrm{S}+\mathrm{SF}$ system had higher wilt incidence. Likewise, the $C / P P-S+S F$ and $\mathrm{S}+\mathrm{SF}-\mathrm{S}+\mathrm{SF}$ cropping systems had higher numbers of soil propagules (1000-2500 $\left.\mathrm{cfu} \mathrm{g}^{-1}\right)$, and greater incidence of wilt. The system with pigeonpea $(\mathrm{S} / \mathrm{PP}-\mathrm{S}+\mathrm{SF})$ had similar numbers of propagules to the $\mathrm{S}+\mathrm{CP}-\mathrm{S}+\mathrm{SF}$, but higher incidence of wilt.

\section{Discussion}

Safflower and sorghum seed yield and biomass varied over years (Figs. 1 and 2), although the different cropping systems exhibited broadly similar ranges of variability. Yield and biomass differed due to complex interactions among several factors including seasonal and within-season rainfall, residual soil moisture during the season, soil temperature (Landa et al., 2001), the residual effect of legumes in rotation (Rego et al., 1989) and disease incidence (Natarajan et al., 1985). As expected, sorghum yields were greatest in rotation with two legumes, cowpea and pigeonpea ( $\mathrm{C} / \mathrm{PP}-\mathrm{S}+\mathrm{SF})$, due almost certainly to greater residual nitrogen effects compared to either one legume $(\mathrm{S}+\mathrm{CP}-\mathrm{S}+\mathrm{SF}$; $\mathrm{S} / \mathrm{PP}-\mathrm{S}+\mathrm{SF})$ or no legumes $(\mathrm{S}+\mathrm{SF}-\mathrm{S}+\mathrm{SF})$. Similar effects on seed yield and biomass of rainy season sorghum cropped with legumes was reported previously (Rego and Nageswara Rao, 2000).

There were significant differences in safflower yield and biomass among cropping systems and the gradual decline in seed yield in the continuous safflower $(S+S F-S+S F)$ system can be attributed to differences in wilt incidence among systems. The difference in severity of wilt incidence was initially due to seedling survival which was associated with the number of soil propagules. The greater rate of wilt progression on surviving plants (greater cumulative AUDPC), also contributed to the lower yield of safflower in the continuous safflower system $(S+S F-S+S F)$ compared to other systems, especially the sorghum and chickpea $(\mathrm{S}+\mathrm{CP}-\mathrm{S}+\mathrm{SF})$ system. In all years, we used safflower seed from the previous year's crop, which might have contributed to the increase in disease incidence (Kalpana Sastry and Chattopadhyay, 1997). Furthermore, F. oxysporum f. sp. carthami inoculum survives in a virulent form in living host tissue (Nelson, 1991) as chlamydospores (Chakrabarti, 1980), and this may be multiplying in the presence of safflower as a host every year. Continuous monocropping often tends to weaken the plants and expose them to soil borne pathogens (Magarey, 1996).

Increased rates of nitrogen application significantly increased safflower seed and biomass yield across all cropping systems, but did not affect either the build-up of propagules in the soil or the severity of wilt. Several studies have indicated that higher nitrogen concentration in the soil can reduce Fusarium wilt. Smiley et al. (1970) observed that the population of Fusarium roseum f.sp. cerealis (Cke.) Snyder and Hansen was reduced due to the fungal toxicity of high concentration of applied ammonia and nitrite in soils. Loeffler et al. (1986) found that the addition of ammonium chloride or urea greatly reduced the population of $F$. oxysporum $\mathrm{f}$. sp. dianthi (Prillieux and Delacroix) Snyder and Hansen, and they concluded that nitrite was responsible for population decline. In contrast, Huber and Waston (1974) reported that increased levels of nitrogen can cause an increase in disease incidence. Nonetheless, our results suggest that intensive cropping of safflower with higher levels of applied nitrogen is a possible strategy to ameliorate the impact of the disease, but does not mitigate against disease pressure per se.

There were clear differences among cropping systems in the number of soil propagules and in the wilt incidence, suggesting that companion crops may influence disease progression and impact. Chickpea-, and to a lesser extent pigeonpea-based systems had lower levels of soil inoculum compared with cowpea and safflower systems. Mandal and Sinha (1991) reported that crop cultivars resistant or tolerant to fungal pathogens produce higher quantities of concentrated exudates to thwart pathogen invasion, while the susceptible genotypes either do not produce root exudates toxic to fungal growth or produce compounds that stimulate pathogen growth. A number of in vitro (Bagawan, 2010; Stevenson et al., 1995), and field studies (Hao et al., 2007) reported that different crops discharge specific root exudates and anti-fungal compunds, such as phenolics, photoalexins, and allelochemicals, into the rhizosphere. For example, wilt-resistant pigeonpea cultivars produced higher quantities of cajanol when Fusarium udam (Butler) was artificially inoculated compared to a susceptible cultivar (Marley and Hillocks, 1993). Likewise, the defence mechanism of 
chickpea to pathogenic fungi is primarily attributed to the production of two pterocarpan phytoalexins, maeckianin and medicarpin (Ingham, 1976), as well as the increased occurrence of antagonistic microflora in rhizophere, which check fungal growth of Fusarium species (Chakrabarti, 1976, 1979; Kolte, 1985).

Odunfa (1978) also observed that sorghum root exudates supressed mycelial growth and inhibited conidial germination of Fusarium compared to a control, possibly because sorghum root exudates contain the anti-fungal substance hydrocyanic acid (Rangaswami and Balasubramanian, 1963) and tannins (Anderson, 1952). Thus the lower rates of wilt incidence and/or the lower build-up of propagules in the soil under systems with sorghum and chickpea, (and pigeonpea to some extent), may be due to their anti-fungal properties, though the cultivars of safflower, pigeonpea, and chickpea used in this study were neither resistant nor tolerant to Fusarium wilt. In contrast, Odunfa (1978) reported that cowpea root exudates containing ninhydrin produced stimulating effects on the conidial germination and mycelial growth of Fusarium species. Higher disease incidence and propagule population in the cowpea/pigeonpea systems could partly be due to cowpea root exudates promoting growth of the fungus especially combined with a wilt-susceptible variety of pigeonpea that might have released low concentrations of root exudate.

Safflower yield can be increased by choosing an appropriate cropping system that may provide an option for areas with high wilt incidence. A respite from safflower cultivation for one year in the post-rainy season by growing chickpea as a sequential crop, or with pigeonpea as an intercrop, combined with higher rates of nitrogen application to safflower, appears to be an effective strategy for reducing Fusarium populations and sustaining safflower yield.

Crop rotations can play a major role in sustaining productivity of intensive cropping systems by controlling soil borne diseases and through rotational effects. The long-term study reported here serves as an early warning system against continuous $\mathrm{S}+\mathrm{SF}$, and with the rotation of $\mathrm{S}+\mathrm{CP}$ every alternate year, provides an effective FOC control strategy. An alternative strategy is identifying Fusarium wilt resistance in safflower varieties (Knowles et al., 1968; Pedgaonkar and Mayee, 1991; Deokar et al., 1997). Kalpana Sastry and Chattopadhyay (2003) screened 51 germplasm lines of safflower and identified three progenies with Fusarium wilt resistance. Further, Raghuwanshi et al. (2004) also evaluated large number of genotypes of safflower against FOC wilt, found inconsistent response of resistance to various FOC races. Singh et al. (2008) reported that none of the existing safflower varieties in India were resistant to Fusarium wilt when screened at disease intensity similar to that found in our study. This may be due to the presence of several races (geographical isolates) of FOC, their tendency to quickly mutate, and selective infectivity on various cultivars of safflower. Therefore, rotation with chickpea is currently the best option for controlling safflower wilt.

Safflower improvement programs in India need time to develop improved varieties and hybrids and evaluate them in multiplication trials before farmers adopt them for commercial production. The development of resistant varieties of safflower in combination with introducing the $\mathrm{S}+\mathrm{CP}-\mathrm{S}+\mathrm{SF}$ rotation could in the future be an effective integrated disease management strategy for controlling Fusarium wilt.

India is the largest producer of safflower (40\% to $60 \%$ of the world's safflower area), with a cultivated area of 0.4 to $0.6 \mathrm{~m}$ ha and average yields of 400 to $700 \mathrm{~kg} \mathrm{ha}^{-1}$ (FAOSTAT, 2011). Since 2003, the area under safflower cultivation has been declining (Kalpana Sastry and Chattopadhyay, 1997), due to disease pressure and terminal droughts. However, since 2007, with increased minimum support prices for grain of sorghum and safflower, the sorghum and safflower double crop system has become more profitable for dryland farmers, and thus the implications of these experimental results are highly relevant.

\section{Conclusions}

Our study demonstrates that a cropping systems approach can be used for managing soil borne wilt of safflower caused by F. oxysporum f. sp. carthami. The inclusion of chickpea in the rotation was effective in reducing the number of Fusarium propagules in the soil and wilt incidence in the field. A break in the rotation with other legumes was less effective, although still better than continuous safflower. Nitrogen had no effect on the number of propagules or on wilt incidence, but did increase yields in all systems, even at high levels of wilt incidence.

\section{References}

Anderson, A.M., 1952. Cause of reddening of roots and effect of fungi on sorghum seedings. Proc. Ass. Offic. Seed Anal. 42, 117

Bagawan, N.B., 2010. In vitro antifungal effect of crop root exudates against Sclerotium rolfsii Sacc. causing stem rot in groundnut. International Journal of plant protection 3 (2), 298-305.

Burke, D.W., Kraft, J.M., 1974. Response of beans and peas to root pathogens accumulated during monoculture of each crop species. Phytopathology 64, 546-549.

Chakrabarti, D.K., 1976. Cultural control of safflower wilt. Intensive Agric. 14 (10), 17.

Chakrabarti, D.K., 1979. Non-host crops, their effect of Fusarium oxysorum f. sp. carthami, Incidence of safflower wilt. PNAS 45 (6), 633.

Chakrabarti, D.K., 1980. Survival of Fusarium oxysporum in soil. Sci. Cult. 46 (2), 65.

Claassen, C.E., 1949. Safflower. Econ. Bot. 3 (2), 143-149.

Colhoun, J., 1958. Club root disease of crucifers caused by Plasmodiophora brassicae Woron. A monograph. Common Wealth Mycol. Inst. Phytopathol. Pap. 3, 108.

Curl, E.A., 1963. Control of plant diseases by crop rotations. Bot. Rev. 29, 413-479.

Deokar, C.D., Shinde, P.B., Akashe, V.a., 1997. Evaluation of host resiEltant against Fusarium wilt in safflower. Sesame Safflower Newsletter 12, 103-105.

FAOSTAT, 2011. Food and Agricultural Organization. FAOSAT, Rome, 〈http://faostat.fao.org/site/339/default.aspx〉.

Hao, Z.P., Wang, Q., Christiea, P., Li, X. L, 2007. Allelopathic potential of watermelon tissue and root exudates. Sci. Hortic. 112, 315-320.

Haware, M.P., Nene, Y.L., Natarajan, M., 8-10, January 1986. Survival of Fusarium oxysporum f. sp. ciceri in soil in the absence of chickpea. In: Abstracts of Paper Presented in National Seminar on Management of Soil Borne Diseases of Crop plants, Coimbatore, Tamilnadu Agricultural University.

Huber, D.M., Waston, R.D., 1974. Nitrogen form and plant disease. Ann. Rev. Phytopath. 12, 139-165.

Huisman, O.C., Ashworth, L.J., 1976. Influence of crop rotations on survival of Verticillium albo-atrum in soils. Phytopathology 66, 978-981.

Ingham, J.L., 1976. Fungal modification of pterocarpan phytoalexins from Melilotus alba and Trijblium pratense. Phytopath. 15, 1489-1495.

Kalpana Sastry, R., Chattopadhyay, C., 2003. Development of Fusarium wilt resistant genotypes in safflower (Carthamus tintorius). Eur. J. Plant Pathol. 109, 147-151.

Kalpana Sastry, R., Chattopadhyay, C., 1997. Viable approaches for effective management of wilt in Safflower. In: Corleto, et al. (Eds.), Safflower: A Multipurpose Species with Unexploited Potential and Wide Adaptability. , pp. 295-298.

Kalpana Sastry, R., 1996. Symptoms of wilt disease-clues for use in resistance breeding. In: Hegde, D.M., Raghavaiah, C.V., Pati, D. (Eds.), Proceedings of Training Programme on Breeding Approaches for Improving Productivity of Safflower and Group Meeting on Heterosis Breeding in Safflower. Directorate of Oilseeds Research, Rajendranagar, Hyderabad, 500030, pp. 25-32.

Kalpana Sastry, R., Jayaraman, J., 1993. Eradication of wilt fungus from heavily infected safflower seed. J. Oilseeds Res. 10, 227-231.

Kalpana Sastry, R., Prasad, M.V.R., Ramachandram, M., June 14-18, 1993. Status of wilt disease of safflower in India. In: Dajue, L., Yuanzhon, H. (Eds.), Proceedings Third International Safflower Conference. Beijing, China, p. 635.

Klisiewicz, J.M., Houston, B.R., 1962. Fusarium wilt of safflower. Plant Dis. Rep. 46, 748-749.

Kampen, J., Krishna, J.H., Pathak, P., 1981. Rainy season cropping on deep vertisols in the semi-arid tropics: effects on hydrology and soil erosion. In: In Tropical Agricultural Hydrology: Watershed Management and Land Use. John Wiley, pp. 257-271.

Kollmorgen, J.F., 1974. The pathogenisity of Fusarium avenaceum to wheat and legumes and its association with crop rotations. Aust. J. Exp. Agric. Anim. Husb. $14,572-576$.

Knowles, P.F., Klisiewicz, J.M., Hill, A.B., 1968. Safflower introductions resistant to Fusarium wilt. Crop Sci, 8 (3), 636-637.

Kolte, S.J., 1985. Diseases of Annual Edible Oilseed Crops, 3. CRC Press, Boca Raton, Honda, FL, pp. 155.

Landa, B.B., Navas-Cortés, J.A., Ana Hervás, Rafael, M., Jiménez-Díaz., 2001. Influence of temperature and inoculum density of Fusarium oxysporum f. sp. ciceris on 
suppression of Fusarium wilt of Chickpea by rhizosphere Bacteria. Phytopathology 91 (8), 807-816.

Loeffler, H.J.M., Van Dongen, V., Schippers, B., 1986. Effect ofammonia on chlamydospore formation of Fusarium oxysporum f. sp. dianthi in an ammonia-flow system. J. Phytopathol. 117, 43-48.

Madden, L.V., Hughes, G., van den Bosch, F., 2007. The Study of Plant Disease Epidemics. APS, Press, St. Paul, MN, USA

Magarey, R.C., 1996. Microbial aspects of sugarcane yield decline. Aust. J. Agric. Res. 46, 307L 322.

Majidi, M.M., Tavakoli, V., Mirlohi, A., Sabzalian, M.R., 2011. Wild safflower species (Carthamus oxyacanthus Bieb.): a possible source of drought tolerance for arid environments. Aust. J. Crop Sci. 5, 1055-1063.

Mandal, N.C., Sinha, A.K., 1991. Differential effects of root exudates and extracts from tomato cultivars on Fusarium oxysporum f. sp. lycopersici in relation to theirdisease reaction. J. Mycopathol. Res. 29, 9-16.

Marley, P.S., Hillocks, R.J., 1993. The role of phytoalexins in resistance to Fusarium wilt in pigeonpea (Cajanus cajan). Plant Pathol. 42, 212-218.

McGregor, W.G., Hay, W.D., 1952. Safflower-Canadian experiments. Sci. Agric. 32, 204-213.

Mourashkinsky, K., 1926. Diseases of the Safflower. Bull. West Siberian Sect. Russ. Geogr. Soc., 5.

Nagarajan, S., Muralidahran, K., 1995. Dynamics of Plant Diseases. Allied Publishers, New Delhi, pp. 247.

Natarajan, M., Kannaiyan, J., Willey, R., Nene, Y.L., 1985. Studies on effects of cropping system on Fusarium wilt of pigeonpea. Field Crop Research, 10. Elsevier Science Publishers B.V, Amsterdam, The Netherlands, pp. 333-346.

Nelson, P.E., 1991. Life cycle and epidemiology of Fusarium oxysporum. In: Mace, et al. (Eds.), Fungal Wilt Diseases of Plants. , pp. 51-79.

Nene, Y.L., Reddy, M.V., Haware, M.P., Ghanekar, A.M., Amin, K.S., 1991. Field diagnosis of chickpea diseases and their control. In: Information Bulletin no. 28. Ed. by International Crops Research Institute for the Semi-Arid Tropics, Patancheru, India.

Odunfa, V.S.A., 1978. Root exudation in cowpea and sorghum and the effect on spore germination and growth of soil Fusaria. New Phytol. 80, 607-612.

Ozturk, E., Ozer, H., Polet, T., 2008. Growth and yield of safflower genotypes grown under irrigated and non-irrigated conditions in a highland environment. Plant Soil Environ. 54 (10), 453-460.

Payne, R.W., Murray, D.A., Harding, S.A., Baird, D.B., Soutar, D.M., 2011. An Introduction to GenStat for Windows (14th ed.). VSN International, Hemel Hempstead, UK.

Pedgaonkar, S.M., Mayee, C.D., 1991. Screening of safflower genotypes and efficacy of seed dressing fungicides against safflower wilt. J. Oilseed Res., 265-270.
Pedgoankar, S.M., Mehta, G.A., Zkurundkar, B.P., 1990. Incidence of safflower wilt in Marathawada Region of Maharastra. J. Maharashtra Agric. Univ. 15 (2) 231-232.

Raghuwanshi, K.S., Dhake, G.N., Pharande, A.L., 2004. Evaluation of safflower genotypes against Fusarium wilt. Journal Sesame and Safflower Newsletter 19.

Rangaswami, G., Balasubramanian, A., 1963. Release of Hydrocyanic acid by sorghum roots and its influence on rhizosphere microflora and plant pathogenic fungi. Indian J. Exp. Biol. 1, 215.

Rego, T.J., Natarajan, M., Saharawat, K.L., Singh, S., Willey, R.W., Burford, J.R., June 11-16, 1989. Residual effects of grain legumes in crop rotations on rainfed Vertisols in SAT India. In: Proceedings International Conference on Soil Quality in Semi-Arid Agriculture, Saskatoon, Saskatchewan, Canada.

Rego, T.J., Nageswara Rao, V., 2000. Long-term Effects of Grain legumes on Rainy Season Sorghum Productivity in a Semi-arid Tropical Vertisol Experimental Agriculture, 36. Cambridge University Press, UK, pp. 1-17.

SAS Institute Inc., 2009. SAS/STAT® Users Guide, Version 9.22. SAS Institute Inc. Cary, North Carolina, USA.

Sharma, S.B., Rego, T.J., Mohiuddin, M., Nageswara Rao, V., 1996. Regulation of Population Densities of Heterodera cajani and Other Plant-Parasitic Nematodes by Crop Rotations on Vertisols in Semi-Arid Tropical Production Systems in India. J. Nematol. 28 (2), 244-251.

Sharma, R.D., Singh, R.S., 1973. A technique for selective isolation of Fusarium moniliforme from soil and plant tissues. Indian J. Mycol. Plant Pathol. 3, 67-70.

Shipton, P.J., 1977. Monoculture and soil borne plant pathogens. Ann. Rev. Phytopathol. 15, 387-407.

Singh, V., Ranaware, A.M., Nimbkar, N., 2008. Breeding for Fusarium wilt resistance in safflower. In: Knights, S.E., Potter, T.D. (Eds.), Safflower: Unexploited Potential and World Adaptability. Proceedings of the 7th International Safflower Conference. Wagga Wagga, New South Wales, Australia http://www. australianoilseeds.com/conferences_workshops/international_safflowerconference $2 /$ conference_proceedings/genetics

Smiley, R.W., Cook, R., Papendick, R.I., 1970. Anhydrous ammonia as a soil fungicide against Fusarium and fungicidal activity in the ammonia retention zone. Phytopathology 60, 1227-1232.

Stevenson, P.C., Padgham, D.E., Haware, M.P., 1995. Root exudates associated with the resistance of four chickpea cultivars (Cicer arietinum) to two races of Fusarium oxysporum f. sp. ciceri. Plant Pathol. 44, 686L 694.

Weiss, E.A., 2000. Oilseed Crops, second ed. Blackwell Science Ltd, Oxford.

Wilhelm, S., 1975. Source and nature of Verticillium wilt resistance in some major crops. In: Bruehl, G.W. (Ed.), Biology and Control of Soil Borne Plant Pathogens. American Phytopathological Society 216 pp, St. Paul, Minn, pp. 166-171. 